\title{
IRREGULARLY MIGRATORY AND RARE WATERBIRD SPECIES WITHIN TWO REPRESENTATIVE WETLANDS FROM THE CENTRAL ROMANIA (SOUTH-EAST TRANSYLVANIA) BASED ON LONG TERM INVENTORY
}

Dan-Traian IONESCU * and Călin Vasile HODOR **

* Transilvania University of Brașov, Faculty of Silviculture and Forest Engineering, Department of Game and Wildlife, Șirul Beethoven Street 1, Brașov, Romania, RO-500036, dionescu@unitbv.ro, ORCID: 0000-0002-0723-1325.

** Wildlife Management Consulting, Ecaterina Varga Street 26, Brașov, Romania, RO-500003, wildlife.consulting@gmail.com, ORCID: 0000-0002-6637-6612.

DOI: 10.2478/trser-2021-0008

KEYWORDS: rare migratory waterbirds, inventory, wetlands, 1994-2020.

\section{ABSTRACT}

Waterbird species from the category of rare or irregular migratory, can have faunistical and conservative value, especially locally, but also regionally or nationally. This paper presents the results of long-term avifauna inventories (25 years) from two wetlands of importance for waterbirds, located in southeastern Transylvania, central Romania. 44 species of waterbirds from these phenological categories have been identified, some for the first time at national or regional level (Transylvania), others with a high number of individuals for the reference area or even records for Transylvania. Moreover, at least one of the species has bred sporadically here, as the only place inside the country and the second in Romania (Ichthyaetus melanocephalus), another is possibly breeding for several years (Grus grus).

RÉSUMÉ: Espèces d'oiseaux d'eau migrateurs irréguliers et rares dans deux zones humides représentatives du centre de la Roumanie (sud-est de la Transylvanie), sur la base d'un inventaire à long terme (1994-2020).

Les espèces d'oiseaux d'eau appartenant à la catégorie des migrateurs rares ou irréguliers, peuvent avoir une valeur faunistique et conservatrice, surtout au niveau local, mais aussi régional ou national. Cet article présente les résultats d'inventaires de l'avifaune à long terme (25 ans) des deux zones humides importantes pour les oiseaux d'eau, situées dans le sud-est de la Transylvanie, au centre de la Roumanie. 44 espèces d'oiseaux d'eau de ces catégories phénologiques ont été identifiées, certaines pour la première fois au niveau national ou régional (Transylvanie), d'autres avec un nombre élevé d'individus pour la zone de référence ou même des enregistrements pour la Transylvanie. En outre, au moins une des espèces s'est reproduite ici de façon sporadique, comme seul endroit du pays et comme deuxième en Roumanie (Ichthyaetusmelanocephalus), une autre se reproduitpeut-être depuis plusieurs années(Grusgrus).

REZUMAT: Specii de păsări de apă rare și cu migrație neregulată din două zone umede reprezentative din centrul României (sud-estul Transilvaniei), conform inventarierii pe termen lung (1994-2020).

Speciile de păsări de apă din categoria celor rare sau a migratoarelor neregulate, pot avea valoare faunistică și conservativă mai ales pe plan local, dar și regional sau național. Lucrarea prezintă rezultatele inventarierilor avifaunistice de lungă durată (25 ani) din două zone umede de importaţă pentru păsările de apă, din sud-estul Transilvaniei, partea centrală a României. Au fost identificate 44 specii de păsări de apă din aceste categorii fenologice, unele fiind specii noi pentru avifauna țării sau pentru Transilvania, altele cu număr de exemplare ridicat pentru zona de referință sau prezentând numărul cel mai mare pentru Transilvania. Cel puțin una dintre specii a cuibărit neregulat aici, ca singurul loc din interiorul țării și al doilea din România (Ichthyaetus melanocephalus), iar o alta este posibil cuibăritoare de câțiva ani (Grus grus). 


\section{INTRODUCTION}

Irregularly migratory and rare bird species can provide important faunistically and conservative information for a given territory, especially based on long-term inventory or monitoring.

In relation to a certain territory, irregularly migratory and also rare bird are species that:

- have usually been identified one-five times over a period of several years or;

- were not observed regularly (annually or almost annually) in one of the two migrations;

- from a quantitative point of view, they usually appear in small numbers (one individual or in small groups).

The definitions of phenological categories on the Rombird Data Base $(* * * * * *)$ were taken into account. We also considered the phenological status of these species at the reference territory level - central Romania, Transylvania.

Why is it important to inventory and centralize bird species in these categories in general or in a reference area?

a. Some of these species are expanding their breeding areas or starting to nest in new territories. An example from our study area is the Mediterranean Gull (Ichthyaetus melanocephalus), which appeared mainly during migration, irregularly and with a small number of individuals, but which sporadically formed small breeding colonies;

b. Other species may change their migration routes or wintering areas, or may use new routes or new wintering areas;

c. Some of them are species of Community interest (Annex I of the Birds Directive) or of different threat categories, such as: SPEC, European Threat Status (Tucker and Evans, 1997) and their occurrence on a territory/habitat may require, updating the standard forms of Natura 2000 sites and then assessing the conservation status of those species;

d. At least for some of them, there is a few data at the level of the reference area (i.e., Bârsa Depression, Brașov County and/or the center of Romania in our case). Any of their reports, especially on long-term observations, with appropriate data on distribution, resting or foraging habitat, or quantitative data are of such interest not only locally but also regionally or nationally, mainly with regard to Romanian bird's distribution maps;

e. From a quantitative point of view, observations on significant groups for the central part of Romania are important in the future, as the studied locations may become stop-over points for an increasing number of individuals;

f. All these situations definitely have practical implications in the conservation of species, populations, and specific habitats for nesting, feeding, resting. Depending on these observations and their analysis, additional conservation measures may be proposed at any time under the management plan of Natura 2000 Sites (i.e., ROSPA0037 in our case), which is an adaptive working tool.

This research focused on relevant man-made wetlands of south-east of Transylvania: Dumbrăviţa (including Dumbrăvița Fishing Complex Ramsar Site) and Rotbav Natura 2000 Site, Special Protection Area (ROSPA0037 Dumbrăviţa-Rotbav-Măgura Codlei) where observations were made on waterbirds for 25 years (1994-2020). 


\section{MATERIAL AND METHODS}

The inventory was carried out on two main man-made wetlands within DumbrăviţaRotbav-Măgura Codlei Natura 2000 Site (N 45 43'10" and E25'24'38”). These are situated at the internal curvature of Carpathians, in the Olt River Basin, a territory in the central side of Romania, Transylvania Province, the intracarpathian region, delimited by the Eastern Carpathians, the Southern Carpathians and, to the west, by the Apuseni Mountains (Fig. 1). The total area of Transylvania has $57.000 \mathrm{~km}^{2}$. The study area is a man-made wetland, one of the most important concentration sites for water birds within Transylvania (Fig. 2). The construction of these artificial wetlands began in the 1970s and continued successively so that after 1985 there were almost all of these man-made wetlands.

The most important habitats for bird's resting and foraging are: deep and shallow water, emergent vegetation, submerged vegetation, willow thick, mud flats, etc. Depending on Ramsar Site wetland types the main such habitats, are: permanent freshwater marshes (Tp), freshwater tree-dominated wetlands (Xf), aquaculture ponds, reservoirs and seasonal/ intermittent freshwater marshes (Ts) $\left.{ }^{* *}\right)$. Some of these habitats (i.e. large waterbodies, mudflats, large areas of emergent vegetation), created by human intervention and by aquaculture management, are completely new compared to the initial ones. Obviously, the trophic source has diversified, especially after the beginning of the fish farming activity (Ionescu et al., 2020).

These kinds of man-made wetlands are recognized as very important or even "key" sites for many vulnerable, rare or endangered bird species and because of that Dumbrăviţa and Rotbav were designated as Important Bird Area (Papp and Fântână, 2008). The Natura 2000 Site has an official management plan comprising several concrete measures for the long-term conservation and maintenance of bird species and populations, in balance with sustainable fish farming $(* * * * * * * * *)$.

Regular or incidentals observations were made on waterbirds species.

In general, we applied the point transect method (Ionescu, 1999; Ionescu, 2002; Ionescu et al., 2008). Different types of binoculars (10x50, 10x45, etc.), scopes (x 20-60) and a professional camera were used during observations. such as:

Some of these data were collected through different monitoring scheme or programs,

Midwinter Count (***);

Global Shorebird Counting which takes place in September (****);

Inventory and monitoring of bird species/populations within the Natura 2000 Site (ROSPA 0037) management plan;

Having regard to the entire observation/inventory period (1994 to 2020), all months and phenological periods (migration, breeding, and wintering) have been completed, but not with a regular observation pressure over the whole period;

The electronic databases were consulted - the online species lists $(* * * * * *, * * * * * * *$, $* * * * * * * *)$. From these databases there were extracted for the studied area all the data related to the species from the targeted categories. 


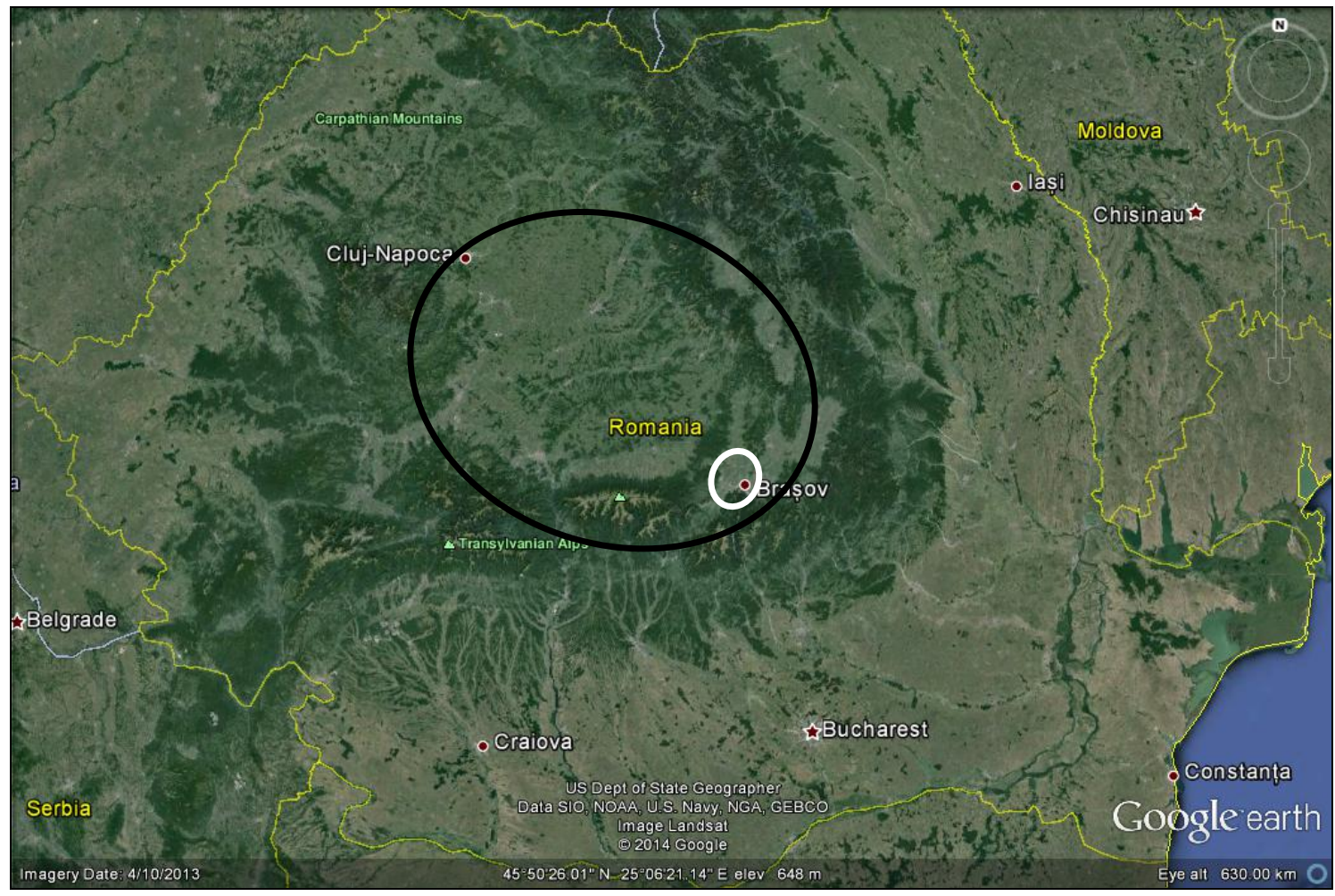

Figure 1: Study area - white are (Brașov Depression as part of Transylvania Province - black area, Romania)

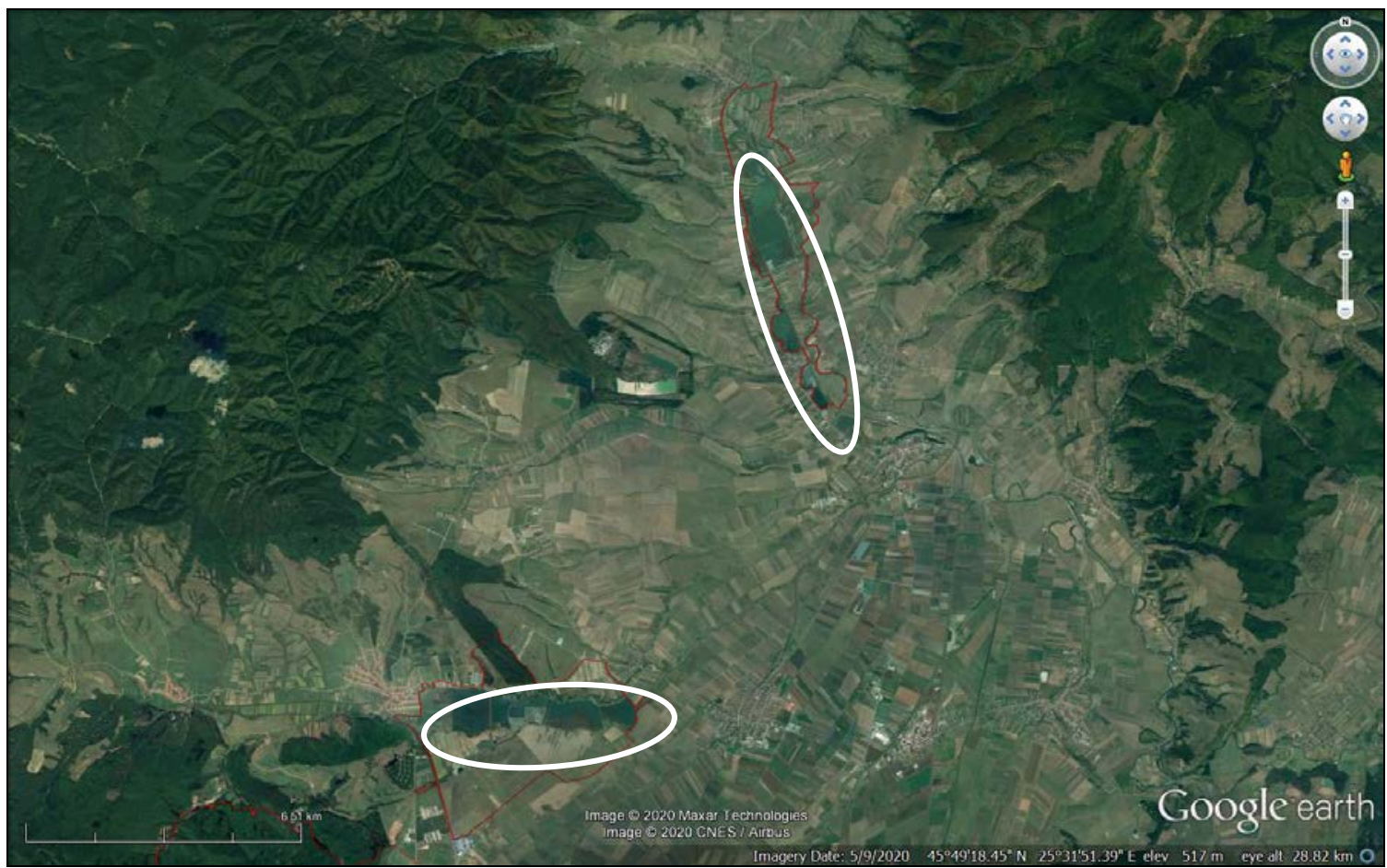

Figure 2: Study area - Dumbrăvița (bottom) and Rotbav wetlands (white areas) within ROSPA0037 (red border). 


\section{RESULTS AND DISCUSSION}

During the considered period, 44 species of waterbirds (Figs. 1-8) from the discussed categories were identified (Tab. 1).

Table 1: Synthesis of our observations and those from the online database ((******, $* * * * * * *, * * * * * * * *)$ within the study area (1994-2020).

\begin{tabular}{|c|c|c|c|}
\hline $\begin{array}{l}\text { Species, location, } \\
\text { habitat type }\end{array}$ & $\begin{array}{c}\text { Years with months of } \\
\text { observation }\end{array}$ & $\begin{array}{l}\text { No. of } \\
\text { ind. } \\
\text { (min, } \\
\max \text { ) }\end{array}$ & $\begin{array}{l}\text { - Comments and comparisons on the } \\
\text { status of the species in Transylvania } \\
\text { (based on Salmen, 1980; Klemm and } \\
\text { Kohl, 1988, online databases) and other } \\
\text { relevant references. }\end{array}$ \\
\hline $\begin{array}{c}\text { Podiceps auritus }^{* 2} \\
\text { D/W }\end{array}$ & $\begin{array}{l}2016-11 \\
2017-03 \\
2019-11\end{array}$ & $1-2$ & $\begin{array}{l}\text { - Considered a rare or irregular migratory } \\
\text { species (Salmen, 1980; Klemm and Kohl, } \\
\text { 1988), quoting some observations from } \\
\text { Transylvania. }\end{array}$ \\
\hline $\begin{array}{l}\text { Pelecanus } \\
\text { onocrotalus }^{* 3} \\
\text { D, R/W, M }\end{array}$ & $\begin{array}{c}1994-04 \\
1997-06 \\
2000-10,11,12 \\
2016-09 \\
2018-06\end{array}$ & $1-2$ & $\begin{array}{l}\text { - Considered migratory (Salmen, 1980) } \\
\text { and rare or irregular migratory (Klemm } \\
\text { and Kohl, 1988), with several historical } \\
\text { observations from Transylvania. Some } \\
\text { data have flocks of several dozen } \\
\text { individuals. } \\
\text { - in Rombird database, there are only three } \\
\text { data locations in Transylvania, in } \\
\text { Openbirdmaps 2, and in Ornitodata, none. }\end{array}$ \\
\hline $\begin{array}{l}\text { Pelecanus } \\
\text { crispus }^{* 3} \\
\text { D/W }\end{array}$ & 25.07 .2014 & 1 & $\begin{array}{l}\text { - Salmen (1980) quotes some historical } \\
\text { observations from Transylvanian. } \\
\text { According to Klemm and Kohl (1988) } \\
\text { there are no new known data. } \\
-\quad \text { in Rombird and Openbirdmaps } \\
\text { databases, there is only one location from } \\
\text { Transylvania (Cipău fishponds, Mureș } \\
\text { County) besides the one in our study area } \\
\text { and in Ornitodata, none. }\end{array}$ \\
\hline $\begin{array}{c}\text { Bubulcus ibis }{ }^{* 3} \\
\text { D/P, S }\end{array}$ & $\begin{array}{c}2013-06 \\
2017-04,05,06,08\end{array}$ & $1-3$ & $\begin{array}{l}\text { - Salmen (1980); Klemm and Kohl (1988) } \\
\text { do not present any observations of the } \\
\text { species in Transylvania. } \\
\text { - our observation in } 2013 \text { was the first } \\
\text { report from the center of Romania. } \\
\text { - in both years, most observations were } \\
\text { within a mixed colony of herons and } \\
\text { cormorants. No definite manifestations of } \\
\text { reproduction were observed, but we do not } \\
\text { exclude a further breeding in the study } \\
\text { area. } \\
- \text { from the three online lists of } \\
\text { observations, there is another report from } \\
\text { Transylvania (Sânpaul, Mureș County) - } \\
\text { Rombird. }\end{array}$ \\
\hline
\end{tabular}




\begin{tabular}{|c|c|c|c|}
\hline $\begin{array}{c}\text { Piegadis } \\
\text { falcinellus }^{* 3} \\
\mathrm{D}, \mathrm{R} / \mathrm{SW}, \mathrm{C}, \mathrm{M}, \mathrm{S}\end{array}$ & $\begin{array}{l}1996-04,05 \\
1999-05 \\
2002-04,05 \\
2005-05 \\
2007-04 \\
2015-04 \\
2017-05,08 \\
2019-04 \\
2020-05,06\end{array}$ & $1-6$ & $\begin{array}{l}\text { - considered a migratory species for } \\
\text { Transylvania (Salmen, 1980; Klemm and } \\
\text { Kohl, 1988); } \\
\text { - on the three on-line database, there are } \\
\text { few observations of the species in the } \\
\text { center of the country; } \\
\text { - six individuals were observed during } \\
\text { May-June } 2020 \text { perched for a while in the } \\
\text { Salix scrubs within the mixed heronry } \\
\text { (Dumbrăvița). }\end{array}$ \\
\hline $\begin{array}{c}\text { Platalea } \\
\text { leucorodia }^{* 3} \\
\mathrm{D}, \mathrm{R} / \mathrm{M}, \mathrm{SW}\end{array}$ & $\begin{array}{c}2002-12 \\
2007-05 \\
2009-05 \\
2011-05 \\
2012-06 \\
2016-06 \\
2019-05,06 \\
2020-05\end{array}$ & $1-3$ & $\begin{array}{l}\text { - considered a migratory species for } \\
\text { Transylvania (Salmen, 1980; Klemm and } \\
\text { Kohl, 1988); } \\
\text { - on the three on-line database, there are } \\
\text { few observations of the species in the } \\
\text { center of the country; } \\
\text { - for a migratory species a special } \\
\text { observation date is 4.12.2002. }\end{array}$ \\
\hline $\begin{array}{c}\text { Cygnus cygnus }^{* 4} \\
\text { D, R/W, I }\end{array}$ & $\begin{array}{l}1994-02,2005-11, \\
2006-03,2012-11, \\
2014-02,03,04,05 \\
12,2015-01,12,2016 \\
-01,11,2017-03\end{array}$ & $1-13$ & $\begin{array}{l}\text { - considered a migratory species or } \\
\text { wintering for Transylvania (Salmen, 1980; } \\
\text { Klemm and Kohl, 1988; } \\
-13 \text { individuals represent one of the } \\
\text { largest identified groups of the species in } \\
\text { the center of the country. }\end{array}$ \\
\hline $\begin{array}{c}\text { Cygnus } \\
\text { columbianus }^{* 3} \\
\mathrm{D} / \mathrm{W}\end{array}$ & $\begin{array}{l}2011-11 \\
2014-03,11 \\
2016-11 \\
2019-11\end{array}$ & $1-8$ & $\begin{array}{l}\text { - Salmen (1980), Klemm and Kohl, (1988) } \\
\text { do not present any observations of the } \\
\text { species in Transylvania; } \\
\text { - our } 2011 \text { observation is the second from } \\
\text { Transylvania, and one of the few within } \\
\text { central Romania; } \\
\text { - eight individuals in group represents the } \\
\text { largest registered number of the species in } \\
\text { central Romania (Transylvania), according } \\
\text { to online database. }\end{array}$ \\
\hline $\begin{array}{c}\text { Branta ruficollis }^{* 3} \\
\text { D, R/W, M, A }\end{array}$ & $\begin{array}{c}2004-11,2007-03, \\
2009-11,12, \\
2011-11,2012-10, \\
11,12,2013-11 \\
2014-10,11 \\
2016-10,11 \\
2017-11,12, \\
2018-02 \\
\end{array}$ & $1-28$ & $\begin{array}{l}\text { - considered a rare or irregular migratory } \\
\text { species for Transylvania (Salmen, 1980; } \\
\text { Klemm and Kohl, 1988); } \\
\text { - } 28 \text { individuals is the largest observed } \\
\text { number in Transylvania, according to } \\
\text { online databases. }\end{array}$ \\
\hline $\begin{array}{l}\text { Branta leucopsis }^{* 1} \\
\text { D/W, M, A, I }\end{array}$ & $\begin{array}{l}2010-10,11 \\
2015-11,12 \\
2016-01\end{array}$ & $1-2$ & $\begin{array}{l}\text { - Salmen (1980), Klemm and Kohl (1988) } \\
\text { do not present any observations of the } \\
\text { species in Transylvania; } \\
\text { - our observation from } 2010 \text { was the first } \\
\text { record from Transylvania. }\end{array}$ \\
\hline $\begin{array}{c}\text { Branta canadensis }^{* 1} \\
\text { D/W }\end{array}$ & 22.05.2018 & 1 & $\begin{array}{l}\text { - Salmen (1980), Klemm and Kohl, (1988) } \\
\text { do not present any observations of the } \\
\text { species in Transylvania; } \\
\text { - our observation was the first record of } \\
\text { this allien specie from Transylvania. }\end{array}$ \\
\hline
\end{tabular}




\begin{tabular}{|c|c|c|c|}
\hline $\begin{array}{c}\text { Anser fabalis }^{* 3} \\
\text { D/W, M, A }\end{array}$ & $\begin{array}{c}1995-10 \\
1996-10 \\
2009-11 \\
2017-10,11 \\
2019-11,12\end{array}$ & $1-5$ & $\begin{array}{l}\text { - considered a migratory species for } \\
\text { Transylvania (Salmen, 1980; Klemm and } \\
\text { Kohl, 1988); } \\
\text { - for the center of the country is a rare } \\
\text { species of goose, with a small number of } \\
\text { identifications and locations (online } \\
\text { database). }\end{array}$ \\
\hline $\begin{array}{l}\text { Tadorna } \\
\text { ferruginea }^{* 3} \\
\mathrm{D} / \mathrm{W}, \mathrm{M}\end{array}$ & $\begin{array}{c}2018-05 \\
2020-03,04\end{array}$ & 1 & $\begin{array}{l}\text { - considered a rare or irregular migratory } \\
\text { species for Transylvania; } \\
\text { - (Salmen, 1980). According to Klemm } \\
\text { and Kohl (1988) there are no new known } \\
\text { data. }\end{array}$ \\
\hline $\begin{array}{c}\text { Netta rufina }^{* 4} \\
\text { D, R/W }\end{array}$ & $\begin{array}{c}1995-04,1999-05, \\
2001-08,2004-05, \\
2005-09, \\
2011-04, \\
2014-03, \\
2016-03,04,05,06, \\
12, \\
2017-04, \\
2018-03, \\
2019-03\end{array}$ & $1-6$ & $\begin{array}{l}\text { - considered a rare or irregular migratory } \\
\text { species for Transylvania } \\
\text { (Salmen, 1980; Klemm and Kohl, 1988). }\end{array}$ \\
\hline $\begin{array}{c}\text { Aythya marila }{ }^{* 4} \\
\text { D, R/W }\end{array}$ & $\begin{array}{c}1994-11,1995-10, \\
1996-11,2004-11, \\
2013-04,2016-11, \\
2017-11\end{array}$ & $1-3$ & $\begin{array}{l}\text { - considered a migratory species or } \\
\text { wintering for Transylvania (Salmen, 1980) } \\
\text { and a rare or irregular migratory species } \\
\text { (Klemm and Kohl, 1988). }\end{array}$ \\
\hline $\begin{array}{l}\text { Clangula } \\
\text { hyemalis }^{* 1} \\
\mathrm{D} / \mathrm{W}\end{array}$ & 1.11 .2003 & 1 & $\begin{array}{l}\text { - considered a rare or irregular migratory } \\
\text { species for Transylvania (Salmen, 1980; } \\
\text { Klemm and Kohl, 1988); } \\
\text { - for the center of the country is a rare } \\
\text { species of duck, with few observations and } \\
\text { locations (online database). }\end{array}$ \\
\hline $\begin{array}{c}\text { Melanitta nigra }^{* 1} \\
\text { D/W }\end{array}$ & 11.12 .2019 & 1 & $\begin{array}{l}\text { - considered a rare or irregular migratory } \\
\text { species for Transylvania (Salmen, 1980; } \\
\text { Klemm and Kohl, 1988); } \\
\text { - for the center of the country is a rare } \\
\text { species of duck, with few observations and } \\
\text { locations (online database); } \\
\text { - the first observation of the species in the } \\
\text { study area belongs to Ilie C. Rombird } \\
\text { database) }\end{array}$ \\
\hline $\begin{array}{c}\text { Melanitta fusca }^{* 2} \\
\text { D/W }\end{array}$ & & $2-5$ & $\begin{array}{l}\text { - considered a rare, irregular migratory or } \\
\text { wintering species for Transylvania } \\
\text { (Salmen, 1980; Klemm and Kohl, 1988); } \\
\text { - for the center of the country is a rare } \\
\text { species of duck, with few observations and } \\
\text { locations (online database); } \\
- \text { the maximum identified number } \\
\text { represents one of the largest groups of the } \\
\text { species in the center of the country (online } \\
\text { database). }\end{array}$ \\
\hline
\end{tabular}




\begin{tabular}{|c|c|c|c|}
\hline $\begin{array}{c}\text { Grus grus }^{* 3} \\
\mathrm{D} \text { (there are also a } \\
\text { few data of one-two } \\
\text { individuals from } \\
\text { Rotbav fishfarm } \\
\text { made by field staff) } \\
\text { /A, M, SW }\end{array}$ & $\begin{array}{c}2001-03,2002-12, \\
2004-10, \\
2007-10,11, \\
2009-05, \\
2012-10, \\
2014-06,12, \\
2017-03,04,05, \\
2018-03,04,09, \\
2019-04,05,06,08, \\
10,11, \\
2020-04,05,06,08\end{array}$ & $1-10$ & $\begin{array}{l}\text { - considered migratory (Salmen 1980) or a } \\
\text { rare or irregular migratory species for } \\
\text { Transylvania (Klemm and Kohl 1988); } \\
\text { - it is important their constant presence } \\
\text { throughout most of the breeding season, } \\
\text { starting with 2017. There is a possibility of } \\
\text { breeding a pair until now or in the future. } \\
\text { The observations from December are also } \\
\text { interesting. }\end{array}$ \\
\hline $\begin{array}{l}\text { Vanellus } \\
\text { leucurus }^{* 3} \\
\text { R/SW }\end{array}$ & 23.04 .2000 & 2 & $\begin{array}{l}\text { - our observation was the first record of } \\
\text { this specie from Transylvania and the } \\
\text { second until now (Salmen, 1980; Klemm } \\
\text { and Kohl, 1988; online database). }\end{array}$ \\
\hline $\begin{array}{l}\text { Haematopus } \\
\text { ostralegus }^{* 4} \\
\text { D, R/M }\end{array}$ & $\begin{array}{l}1996-08, \\
2008-05, \\
2010-03, \\
2016-08, \\
2017-09, \\
2020-03\end{array}$ & $1-3$ & $\begin{array}{l}\text { - considered a rare or irregular migratory } \\
\text { species for Transylvania (Salmen, 1980; } \\
\text { Klemm and Kohl, 1988). }\end{array}$ \\
\hline $\begin{array}{l}\text { Recurvirostra } \\
\text { avoseta }^{* 4} \\
\text { D, R/M, SW }\end{array}$ & $\begin{array}{c}1996-06, \\
2001-04, \\
2005-04,05, \\
2007-04, \\
2008-04,05,07, \\
2009-03,05, \\
2012-06, \\
2014-09, \\
2015-03,04, \\
2016-03,04, \\
2017-03,04,05, \\
2018-04, \\
2019-09, \\
2020-04,07\end{array}$ & $1-11$ & $\begin{array}{l}\text { - considered migratory (Salmen, 1980) or } \\
\text { a rare or irregular migratory species for } \\
\text { Transylvania (Klemm and Kohl, 1988). }\end{array}$ \\
\hline $\begin{array}{l}\text { Pluvialis } \\
\text { apricaria }^{* 4} \\
\text { D/M }\end{array}$ & $\begin{array}{c}2001-10, \\
2006-09,10, \\
2007-03 \\
2013-03 \\
2018-10\end{array}$ & $1-2$ & $\begin{array}{l}\text { - considered migratory or wintering } \\
\text { species for Transylvania (Salmen, 1980; } \\
\text { Klemm and Kohl, 1988). }\end{array}$ \\
\hline $\begin{array}{c}\text { Calidris } \\
\text { temminckii } \\
\mathrm{D}, \mathrm{R} / \mathrm{M}\end{array}$ & $\begin{array}{c}1995-09, \\
2005-09, \\
2007-07, \\
2009-04,08, \\
2010-08, \\
2014-08,09, \\
2015-08, \\
2016-08,09, \\
2017-04, \\
2018-09, \\
2019-07, \\
2020-07\end{array}$ & $1-8$ & $\begin{array}{l}\text { - considered migratory (Salmen, 1980) or } \\
\text { a rare or irregular migratory species for } \\
\text { Transylvania (Klemm and Kohl, 1988); } \\
\text { - the maximum identified number } \\
\text { represents one of the largest groups of the } \\
\text { species in the center of the country (online } \\
\text { database). }\end{array}$ \\
\hline
\end{tabular}




\begin{tabular}{|c|c|c|c|}
\hline $\begin{array}{c}\text { Calidris alba }{ }^{* 4} \\
\text { D/M, CS }\end{array}$ & $\begin{array}{c}1997-09, \\
2003-09, \\
2008-09, \\
2009-08,09, \\
2010-09, \\
2013-09, \\
2016-08,09, \\
2017-09,2018-09 \\
\end{array}$ & $1-4$ & $\begin{array}{l}\text { - considered with the sign ? (Salmen, } \\
\text { 1980) or rare or irregular migratory for } \\
\text { Transylvania (Klemm and Kohl, 1988). }\end{array}$ \\
\hline $\begin{array}{c}\text { Calidris canutus }^{* 1} \\
\text { D/M }\end{array}$ & 10.09 .2018 & 1 & $\begin{array}{l}\text { - considered with the sign ? (Salmen, } \\
\text { 1980) or rare or irregular migratory for } \\
\text { Transylvania (Klemm and Kohl, 1988); } \\
\text { - there are a few observations and } \\
\text { locations in Transylvania (online database). }\end{array}$ \\
\hline $\begin{array}{l}\text { Calidris } \\
\text { falcinellus }^{* 1} \\
\mathrm{D}, \mathrm{R} / \mathrm{M}\end{array}$ & $\begin{array}{c}1995-09, \\
2009-08,09, \\
2013-08,09, \\
2016-08,09, \\
2019-09\end{array}$ & $1-4$ & $\begin{array}{l}\text { - considered migratory (Salmen, 1980) or } \\
\text { a rare or irregular migratory species for } \\
\text { Transylvania (Klemm and Kohl, 1988). }\end{array}$ \\
\hline $\begin{array}{c}\text { Lymnocryptes } \\
\text { minimus } \\
\text { D/MS } \\
\end{array}$ & 21.04 .2004 & 1 & $\begin{array}{l}\text { - considered migratory (Salmen, 1980) or } \\
\text { a rare or irregular migratory species for } \\
\text { Transylvania (Klemm and Kohl, 1988). }\end{array}$ \\
\hline $\begin{array}{c}\text { Limosa lapponica }^{* 2} \\
\text { D, R/M, SW }\end{array}$ & $\begin{array}{c}2007-09,10, \\
2013-09\end{array}$ & 1 & $\begin{array}{l}\text { - considered a rare or irregular migratory } \\
\text { species for Transylvania (Salmen, 1980; } \\
\text { Klemm and Kohl, 1988); } \\
\text { - there are a few locations of observation } \\
\text { in Transylvania (online database). }\end{array}$ \\
\hline $\begin{array}{l}\text { Numenius } \\
\text { phaeopus* }^{3} \\
\text { D/M, CS }\end{array}$ & $\begin{array}{l}2009-04 \\
2018-04 \\
2019-07 \\
2020-04\end{array}$ & $1-2$ & $\begin{array}{l}\text { - considered migratory (Salmen, 1980) or } \\
\text { a rare or irregular migratory species for } \\
\text { Transylvania (Klemm and Kohl, 1988); } \\
\text { - there are a few locations of observation } \\
\text { in Transylvania (online database). }\end{array}$ \\
\hline $\begin{array}{c}\text { Tringa stagnatilis } \\
\text { D, R/M, CS }\end{array}$ & $\begin{array}{c}1996-04, \\
2001-04, \\
2007-04, \\
2008-04,09, \\
2009-04 \\
2013-09 \\
2017-04 \\
2018-04\end{array}$ & $1-5$ & $\begin{array}{l}\text { - considered migratory (Salmen, 1980) or } \\
\text { a rare or irregular migratory species for } \\
\text { Transylvania (Klemm and Kohl, 1988). }\end{array}$ \\
\hline $\begin{array}{c}\text { Arenaria } \\
\text { interpres }^{4} \\
\mathrm{D}, \mathrm{R} / \mathrm{M}\end{array}$ & $\begin{array}{l}1995-08,09,1996- \\
09,1997-09,2003- \\
09,2004-09,2008- \\
05,2013-09,2016- \\
08,09 .\end{array}$ & $1-8$ & $\begin{array}{l}\text { - considered a rare or irregular migratory } \\
\text { species for Transylvania (Salmen, 1980; } \\
\text { Klemm and Kohl, 1988). }\end{array}$ \\
\hline $\begin{array}{l}\text { Phalaropus } \\
\text { lobatus }^{*}\end{array}$ & $\begin{array}{c}1996-09, \\
1997-08,09, \\
2005-09, \\
2006-08, \\
2013-09, \\
2014-09,2015-08, \\
2020-08\end{array}$ & $1-17$ & $\begin{array}{l}\text { - considered migratory (Salmen, 1980) or } \\
\text { a rare or irregular migratory species for } \\
\text { Transylvania (Klemm and Kohl, 1988); } \\
\text { - the maximum number is the largest } \\
\text { observed in Transylvania (online } \\
\text { database). }\end{array}$ \\
\hline
\end{tabular}




\begin{tabular}{|c|c|c|c|}
\hline $\begin{array}{c}\text { Glareola } \\
\text { pratincola* } \\
\text { D/M } \\
\end{array}$ & $\begin{array}{l}2008-05 \\
2015-10\end{array}$ & 1 & $\begin{array}{l}\text { - considered migratory (Salmen, 1980) or } \\
\text { a rare or irregular migratory species for } \\
\text { Transylvania (Klemm and Kohl, 1988). }\end{array}$ \\
\hline $\begin{array}{l}\text { Stercorarius } \\
\text { parasiticus } *^{3} \\
\text { D/M }\end{array}$ & $\begin{array}{l}1995-09 \\
2014-09 \\
2015-08\end{array}$ & $1-5$ & $\begin{array}{l}\text { - considere migratory (Salmen, 1980) or a } \\
\text { rare or irregular migratory species for } \\
\text { Transylvania (Klemm and Kohl, 1988); } \\
\text { - there are a few locations of observation } \\
\text { in Transylvania (online database); } \\
\text { - the maximum number is the largest } \\
\text { observed in Transylvania (online database). }\end{array}$ \\
\hline $\begin{array}{l}\text { Ichthyaetus } \\
\text { melanocephalus* } \\
\text { D, R/M, W }\end{array}$ & $\begin{array}{c}1996-05,06, \\
1998-04,06, \\
2007-05, \\
2008-05, \\
2009-04,05, \\
2010-10, \\
2011-05, \\
2013-05,06,07 \\
2014-03,04, \\
2016-08,02 \\
2018-04, \\
2019-04, \\
2020-03,05,06,07\end{array}$ & $1-20$ & $\begin{array}{l}\text { - considered rare or irregular migratory } \\
\text { species for Transylvania (Klemm and } \\
\text { Kohl, 1988), the species does not appear in } \\
\text { Salmen's monograph (1980); } \\
\text { - the maximum identified number } \\
\text { represents one of the largest groups of the } \\
\text { species in Transylvania (online database); } \\
\text { - in addition to the individuals that migrate } \\
\text { through the study area, it bred in two years } \\
\text { at Rotbav (2013, 2020), this being the } \\
\text { second or the third breeding place (Ionescu } \\
\text { et al., 2015; Keller et al., 2020) of the } \\
\text { species in Romania and for the first time in } \\
\text { the center of the country (Ionescu et al., } \\
2015 \text { ); } \\
\text { - thus, for 2013, 3-12\% of the national } \\
\text { population bred at Rotbav (*, 2015). For } \\
2020,2.5-20 \% \text { of the national population } \\
\text { bred at Rotbav (********); } \\
\text { - therefore, its presence here is very } \\
\text { important not only for the area, but also at } \\
\text { national level, and a stable microcolony } \\
\text { can be formed in the future, if the habitat } \\
\text { conditions allow. }\end{array}$ \\
\hline $\begin{array}{l}\text { Chroicocephalus } \\
{\text { genei } *^{3}} \\
\mathrm{D} / \mathrm{M}\end{array}$ & 06.03.2017 & 1 & $\begin{array}{l}\text { - Salmen (1980), Klemm and Kohl } \\
\text { (1988) do not present any observations of } \\
\text { the species in Transylvania; } \\
\text { - this is the 3rd observation of the species } \\
\text { in Transylvania, until now (online } \\
\text { database). }\end{array}$ \\
\hline $\begin{array}{c}\text { Larus fuscus }^{* 4} \\
\text { D/M, W }\end{array}$ & $\begin{array}{l}1996-09,2002-09 \\
10,2003-11,2005- \\
05,2006-09,2008- \\
04,2013-10,2014- \\
09,2015-07,09,10 \\
2016-10 ; 2017-04 \\
05,2019-04,10,11\end{array}$ & $1-120$ & $\begin{array}{l}\text { - considered migratory (Salmen, 1980) or } \\
\text { a rare or irregular migratory species for } \\
\text { Transylvania (Klemm and Kohl, 1988); } \\
\text { - the maximum number recorded by us } \\
\text { (over } 120 \text { individuals on 28.09.2015) is the } \\
\text { largest number of the species for central } \\
\text { Romania (record for Transylvania) and } \\
\text { one of the largest in Romania (Salmen, } \\
\text { 1980; Munteanu, 1982; Klemm and Kohl, } \\
\text { 1988; online database). }\end{array}$ \\
\hline
\end{tabular}




\begin{tabular}{|c|c|c|c|}
\hline $\begin{array}{c}\text { Larus glaucoides }^{*}{ }^{1} \\
\text { D/W, I }\end{array}$ & 13.01 .2016 & 1 & $\begin{array}{l}\text { - our observation (13.01.2016) is the first } \\
\text { definite proof of the species for Romania } \\
\text { and the only one until August } 2020 \\
\text { (Salmen, 1980; Klemm and Kohl, 1988; } \\
\text { online database). }\end{array}$ \\
\hline $\begin{array}{c}\text { Larus ichtyaetus*3 } \\
\mathrm{D} / \mathrm{W}\end{array}$ & 15.10. 2019 & 1 & $\begin{array}{l}\text { - Salmen (1980), Klemm and Kohl (1988) } \\
\text { do not present any observations of the } \\
\text { species in Transylvania; } \\
\text { - there are a few locations of observation } \\
\text { in Transylvania (online database); } \\
\text { - the first observation of the species in the } \\
\text { study area belongs to Pál L. (Rombird } \\
\text { database). }\end{array}$ \\
\hline $\begin{array}{l}\text { Hydroprogne } \\
\text { caspia }^{* 4} \\
\text { D, R/W }\end{array}$ & $\begin{array}{c}1996-04,09, \\
2007-04, \\
2008-09, \\
2009-08, \\
2014-04, \\
2015-08, \\
2016-08,2 \\
018-04,05, \\
2019-07\end{array}$ & $1-3$ & $\begin{array}{l}\text { - considered rare or irregular migratory } \\
\text { species for Transylvania (Salmen, 1908; } \\
\text { Klemm and Kohl, 1988). }\end{array}$ \\
\hline $\begin{array}{l}\text { Gelochelidon } \\
\text { nilotica* } *^{3} \\
\text { D/W }\end{array}$ & $\begin{array}{l}2004-07 \\
2007-07 \\
2008-06 \\
2020-06\end{array}$ & $1-3$ & $\begin{array}{l}\text { - considered migratory (Salmen, 1980) or } \\
\text { a rare or irregular migratory species for } \\
\text { Transylvania (Klemm and Kohl, 1988). }\end{array}$ \\
\hline $\begin{array}{c}\text { Sterna } \\
\text { sandvicensis* } *^{3} \\
\mathrm{D} / \mathrm{R}\end{array}$ & 06.06 .2019 & 1 & $\begin{array}{l}\text { - Salmen (1980), Klemm and Kohl (1988) } \\
\text { do not present any observations of the } \\
\text { species in Transylvania; } \\
- \text { this is a rare tern species in the central } \\
\text { of Romania with a few locations of } \\
\text { observation in Transylvania (online } \\
\text { database). }\end{array}$ \\
\hline $\begin{array}{c}\text { Sternula albifrons } *^{3} \\
\text { D/W, M }\end{array}$ & $\begin{array}{c}2005-06 \\
2008-07 \\
2012-06 \\
2014-06 \\
2016-06,08\end{array}$ & $1-3$ & $\begin{array}{l}\text { - considered migratory (Salmen, 1980) or } \\
\text { a rare or irregular migratory species for } \\
\text { Transylvania (Klemm and Kohl, 1988); } \\
\text { - this is a rare tern species in the central of } \\
\text { Romania with a few locations of } \\
\text { observation in Transylvania (online } \\
\text { database). }\end{array}$ \\
\hline
\end{tabular}

D - Dumbrăvița area; R - Rotbav area; 01, 02....12 - the months of observations.

* - species of Community interest (annex I of the Birds Directive).

** - in the table we mentioned the author of the first identification if this did not belong to us. Habitat types:

W - water body of lakes, reservoirs or fishponds; SW - shallow water; M - mudflat; MS marsh; $\mathrm{R}$ - reedbed or other types of emergent vegetation; $\mathrm{C}$ - canals; CS - concrete shore; $\mathrm{P}$ pasture; A - arable land, crops; S - willow scrubs; I - ice on water body. 
Classification of the status of species according to the online platform for ornithological observations (******):

1 - very rare or rare species at national level (accidental or regularly occurring species in very small numbers annually). They usually have a few dozen or up to a hundred observations in Romania;

${ }^{2}$ - rare species at national level (species with regular annual occurrence, usually occurring in small numbers, species that appear in the form of invasion or that appear only in a few restricted areas, very localized in the country);

${ }^{3}$ - very rare or accidental species regionally. These species may be common in other geographical areas (i.e. white pelican in Dobrogea or Bărăgan - south of Romania), but accidental in others, such as Transylvania;

${ }^{4}$ - rare or sporadic species at regional level (species with annual or near-annual occurrence and in relatively small numbers).

After the period we considered, new species were identified for the area: Stercorarius pomarinus (Rotbav, 18.10.2020, observed by Daroczi Sz., ******), Anser erythropus (Dumbrăvița, 10.11. 2020, observed by Ilie C., ******).

Most species belong to the systematic groups of: waders (15 species), swans, geese, and ducks (12 species), skuas, gulls, and terns (10 species).

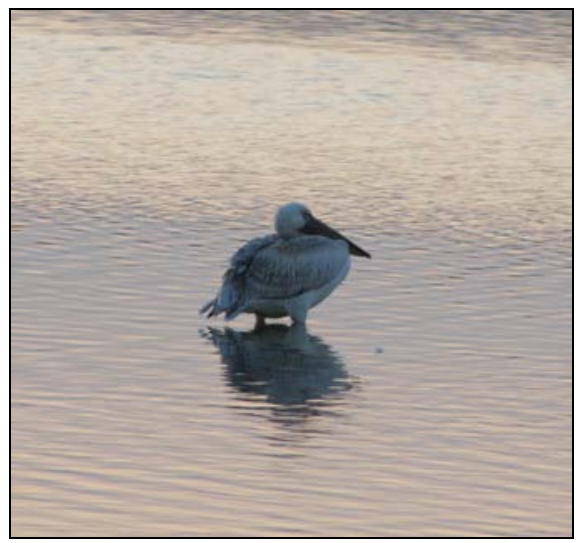

Figure 1: Pelecanus onocrotalus (Ionescu, 12.09.2016, Dumbrăvița).

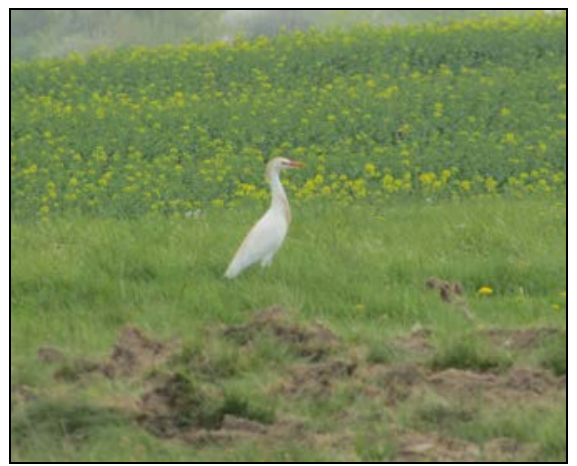

Figure 2: Bubulcus ibis (Ionescu, 29.04.2017, Dumbrăvița). 


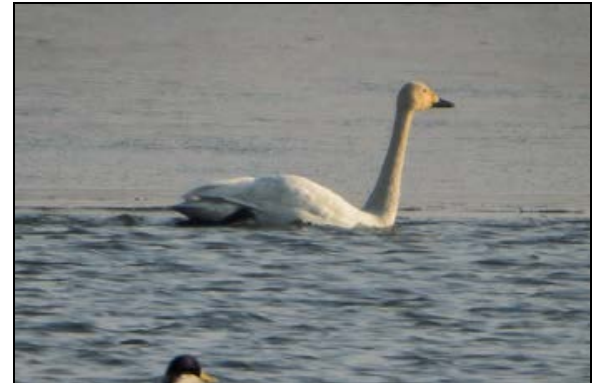

Figure 3: Gygnus columbianus (Ciungara, 24.11.2011, Dumbrăvița).

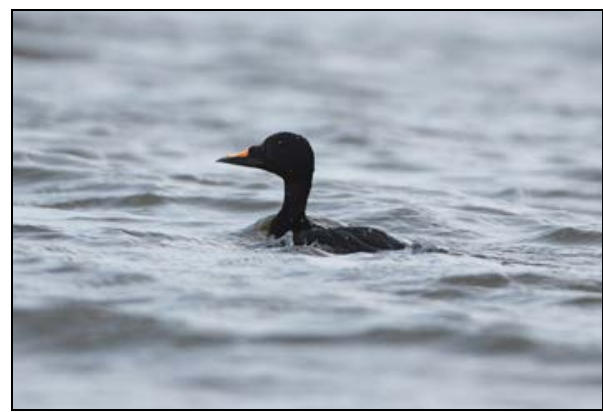

Figure 4: Melanitta nigra (Fuciu, 13.11.2019, Dumbrăvița).

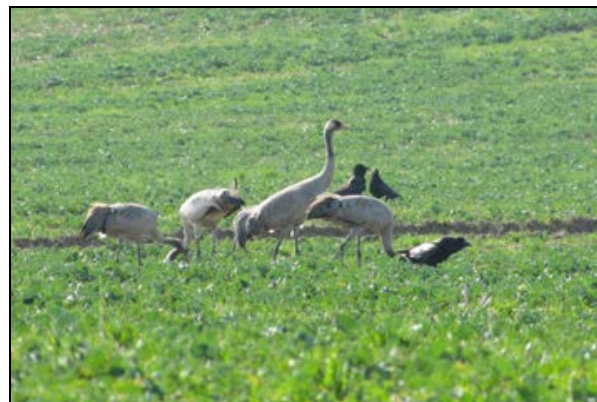

Figure 5: Grus grus (Ionescu, 30.03.2017, Dumbrăvița).

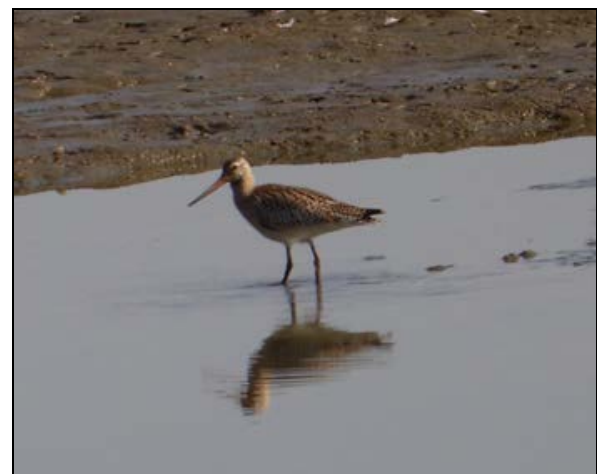

Figure 6: Limosa lapponica (Ionescu, 30.09.2007, Dumbrăvița). 


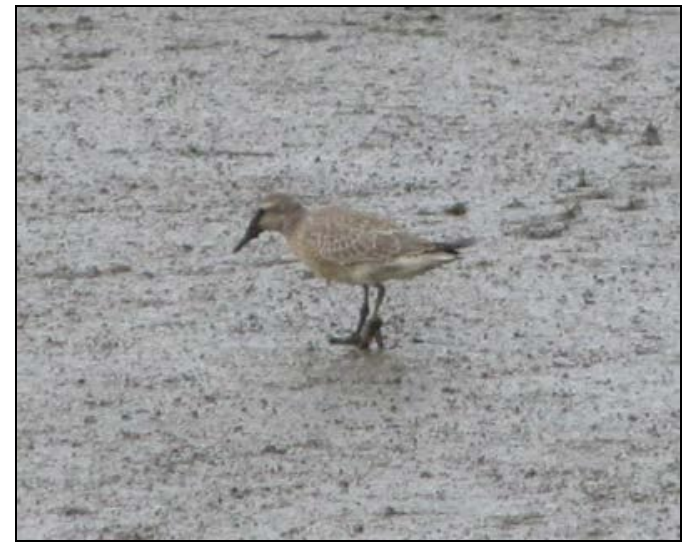

Figure 7: Calidris canutus (Ionescu, 12.09.2018, Dumbrăvița).

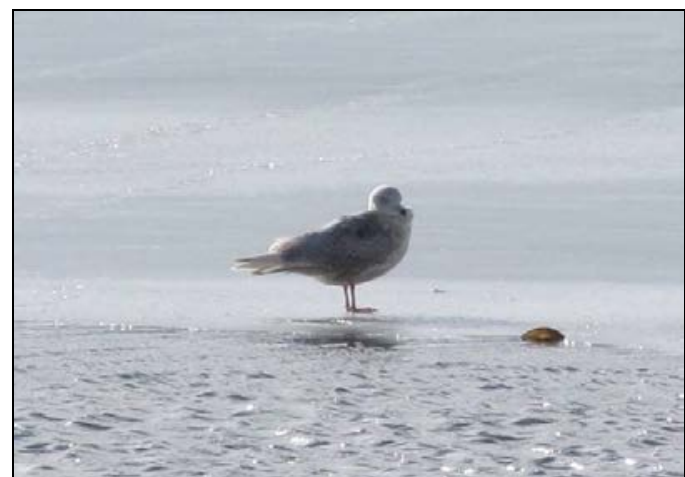

Figure 8: Larus glaucoides (Ionescu, 13.01.2016, Dumbrăvița).

There is a variation in the total number of species or in different systematic groups, by months, seasons and main phenological periods. The months with the highest total number of species were April and September (17 species), followed by May and August (14 species). Swans, geese and ducks have the highest number of species in autumn and early winter, due to the appearance of northern species. The highest number of waders species was recorded in the months of migration: September, August and April. Concerning the distribution of the total number of species records by seasons, autumn and spring have the highest number (44 and 40 records, respectively). Distribution of the number of species records by main phenological periods is also variable, both in the total number of species and in main systematic groups (Tab. 2).

Table 2: Distribution of the number of species records (the most important systematic orders) by main phenological periods.

\begin{tabular}{|c|c|c|c|}
\hline $\begin{array}{c}\text { No. } \\
\text { of species } \\
\text { records }\end{array}$ & $\begin{array}{c}\text { Spring migration } \\
\text { (months: 03, 04, 05) }\end{array}$ & $\begin{array}{c}\text { Autumn migration } \\
\text { (months: 08-11) }\end{array}$ & $\begin{array}{c}\text { Wintering (months: } \\
\text { 01, 02, 12) }\end{array}$ \\
\hline Swans, geese, ducks & 12 & 15 & 12 \\
\hline Waders & 13 & 20 & - \\
\hline Skuas, gulls, terns & 9 & 10 & 1 \\
\hline
\end{tabular}


As expected in the two migration periods, the highest number of species was identified.

In terms of feeding and resting habitat, most species were attracted to mudflat (26 species) and water body (21 species). Through the integrated management of the Natura 2000 Site at any time of the year there are filled lakes or fishponds, and during the autumn migration (August-November) mudflat habitats and possibly with shallow water. The management plan of ROSPA0037 provides that during the autumn migration the fishponds will be drained (this is the usual fish harvesting time and method) so that the birds benefit from the mudflat and shallow water habitats. Practically all the species discussed currently benefit from improved habitat and food conditions or completely new ones compared to those before human interventions in the years 1970-1980.

From a quantitative point of view, the number of species by categories of maximum numbers shows that most species fall into the category 1-5 individuals (73\%). Only one species had a maximum number of over 101 individuals (table 3 ).

From a quantitative point of view, the number of species by categories of maximum numbers shows that most species fall into the category 1-5 individuals (73\%). Only one species had a maximum number of over 101 individuals (table 3 ).

Table 3: Distribution of the number of species by categories of maximum number of individuals.

\begin{tabular}{|c|c|c|c|c|c|}
\hline \multirow{2}{*}{$\begin{array}{c}\text { No. of } \\
\text { species }\end{array}$} & \multicolumn{5}{|c|}{$\begin{array}{c}\text { Categories } \\
\text { of maximum number of individuals }\end{array}$} \\
\cline { 2 - 6 } & $1-5$ & $6-10$ & $11-20$ & $21-100$ & $>101$ \\
\hline $\begin{array}{c}\text { Total } \\
\text { nomber of } \\
\text { species }\end{array}$ & 32 & 6 & 4 & 1 & 1 \\
\hline $\begin{array}{c}\text { Swans, } \\
\text { geese, } \\
\text { ducks }\end{array}$ & 8 & 2 & - & 1 & - \\
\hline Waders & 11 & 2 & 2 & - & - \\
\hline $\begin{array}{c}\text { Skuas, } \\
\text { gulls, } \\
\text { terns }\end{array}$ & 8 & - & 1 & - & 1 \\
\hline
\end{tabular}

As we pointed out, species from rare or irregular migratory categories can also be of conservative interest. Of the 44 species considered, half (22 species) are of Community interest (included in Annex I of the Birds Directive). In this regard, all data on species of Community interest, concerning presence, numbers, habitats, etc. they are of priority and can scientifically support various further management decisions. 


\section{CONCLUSIONS}

Data on rare or irregular migratory bird species are important as part of local avifauna inventory, but sometimes also at regional or national level. All these species are attracted by various habitat and food conditions, especialy within man-made wetlands such as fish farms as part of Natura 2000 Sites (SPAs) where integrated management is applied. In this sense, fish farms are feeding areas and stop-over areas of prime importance for birds that require continuity of fisheries management, including the drainage of ponds in autumn or spring.

The inventory of local avifauna will continue and focus on species of community interest for the further management measures especially if their frequency or number of individuals will increase, or if they change their phenological status (i.e. they become breeding species, regular wintering or passage species, etc.).

The creation of databases on avifauna, which also includes rare or irregularly migratory species and their publication are desirable for all wetlands in Romania, with an emphais on man-made ones. It would also be necessary a general and comparative study of biodiversity/avifauna within man-made wetlands (reserviors, artificial lakes, and fishponds) in Romania and possibly the publication of a monograph in this regard. 


\section{ACKNOWLEDGEMENTS}

This work has been supported by S.C. Wildlife Management Consulting S.R.L. We thank to all ornithologists, photographers, and birders who made observations within the study area. We also thank the Doripesco Fishing Company for ensuring access to the fish farms and for the integrated management of the protected area. 


\section{REFERENCES}

1. Hodor V. C., 1997 - Contribuții la studiul ornitofaunei din complexul de lacuri de la Rotbav, judeţul Brașov, Lucrările celei de-a treia Conferințe Naționale pentru Protecția Mediului prin Metode și Mijoace Biologice și Biotehnologii, Brașov, 409-415. (in Romanian)

2. Ionescu D. T., 1998 - Contribuții la studiul structurii și dinamicii păsărilor din unele zone umede ale Depresiunii Bârsei, Lucrările celei de-a treia Conferințe Naționale pentru Protecția Mediului prin Metode și Mijoace Biologice și Biotehnologii, Braşov, 375-380. (in Romanian)

3. Ionescu D. T., 1999 - Contributions to the study of the waterfowl from Dumbrăviţa Lake and ponds (Bârsa Depression), Transylvania Review of Systematical and Ecological Research, 1, 191195.

4. Ionescu D. T., 2002 - Aspecte ale migraţiei păsărilor de apă în Depresiunea Bârsei, Transilvania, România, Analele Banatului, 109-119. (in Romanian)

5. Ionescu D. T., Popescu V. and Iordache D., 2008 - Data concerning the designation of Dumbrăvița (Romania) Complex as Ramsar Site, Transylvania Review of Systematical and Ecological Research, 6, 185-190.

6. Ionescu D. T., Iordache D. and Popescu V., 2015 - New breeding bird species of community interest within wetlands from the central side of Romania, Forest and sustainable development, Faculty of Silviculture and Forest Engineering Brașov, 363-368.

7. Ionescu D. T., Hodor V. C. and Petrițan I. C., 2020 - Artificial wetlands as breeding habitats for colonial waterbirds within central Romania, Diversity, 12, 10, 371.

8. Keller V., Herrando S., Voř́íšek P., Franch M., Kipson M., Milanesi M., Martí D., Anton M., Klvaňová A., Kalyakin M. V., Bauer H.-G. and Foppen R. P. B., 2020 - European breeding bird atlas 2: distribution, abundance and change, Europeean Bird Census Council and Lynx Edicions, Barcelona, 967.

9. Klemm W. and Kohl Ș., 1988 - Die Ornis Siebenburgens, Böhlau Verlag, Wien, Köln (in German, 469.

10. Munteanu D., 1982 - Pescăruşul negricios (Larus fuscus L.) în România, Studii şi Comunicări, II, 415-426. (in Romanian)

11. Papp T. and Fântână C. (eds.), 2008 - Important bird areas in Romania, Publication by Romanian Ornithological Society and Association “Milvus Group”, Târgu-Mureș, 319.

12. Salmen H., 1980 - Die Ornis Siebenburgens, Böhlau Verlag, Wien, Köln, 454. (in German)

13. Tucker G. M. and Evans M. I., 1997 - Habitats for birds in Europe: a conservation strategy for the wider environment, Cambridge, BirdLife International, 464.

14. *, 2015 - Atlas al speciilor de păsări de interes comunitar din România, Ministerul Mediului, Apelor și Pădurilor, București, 608. (in Romanian)

15. ** https://rsis.ramsar.org/RISapp/section.php?idSection=25\&part=62\&idvris=53484791\&action= view

16. $* * *$ - https://www.sor.ro/proiect/international-waterbird-count/

17. $* * * *-$ https://www.worldshorebirdsday.org/global-shorebird-counts

18. $* * * * *$ - https://eur-lex.europa.eu/legal-content/EN/TXT/?uri=CELEX:32009L0147

19. $* * * * * *-\mathrm{https}: / /$ rombird.ro/

20. $* * * * * * *-$ https://openbirdmaps.ro/

21. $* * * * * * * *$ - http://pasaridinromania.sor.ro/ornitodata

22. $* * * * * * * * * \quad$ - http://www.anpm.ro/documents/15795/2964930/PLAN+MANAGEMENT+Dumb ravita-Rotbav-Magura+Codlea.pdf/8b94f816-11b3-427a-b08e-5d96d7a91533

23. $* * * * * * * * * * \quad$ - http://cdr.eionet.europa.eu/ro/eu/art12/envxtwkg/RO_birds_reports_20200727125003.xml/manage_document 